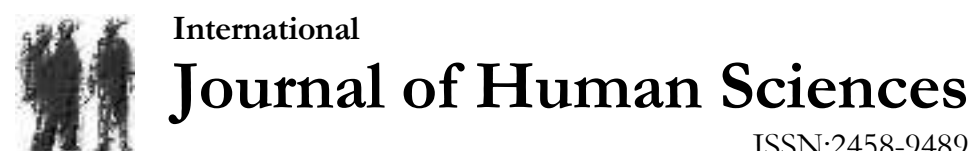

Volume 17 Issue 4 Year: 2020

\section{Determination of the relationship between physician trust, medical mistrust, and self-confidence in the health services provided in Turkey}

\author{
Halil Sengul ${ }^{1}$ \\ Arzu Bulut ${ }^{2}$
}

\begin{abstract}
Objectives: A sense of trust is of great importance for professional professions. Failure to establish trust, especially in an industry where information asymmetry is too high, such as the health sector, also poses important problems for both employees and society. In this study, we aimed to identify variables that affect the distrust of the health system and trust in the physician.

Material and Method: This study was carried out in the descriptive design. The study group consisted of 561 people living in different cities of Turkey and whose ages ranged from 18-70 years. "Personal data form", " Medical mistrust scale", "Physician trust scale" and "generalized trust inventory infrastructure scale" were used as data collection tools prepared by the researcher. As a data collection method, the test method performed in a computer environment was used. One-way analysis of variance from parametric test statistics and Pearson correlation analysis test statistics were used to compare data. $\mathrm{P}<0.050$ and $\mathrm{p}<0.001$ were determined for the significance level.

Results: In our study, medical mistrust decreased as trust in the physician increased. As a person's level of self-trust increases, medical mistrust increases, and confidence in the physician also decrease. Dissatisfaction with the health service increases medical mistrust, while also reducing trust in the physician. Based on the preferred type of hospital, the level of medical mistrust of patients going to private hospitals is greater than the level of medical mistrust of patients going to public hospitals.

Conclusion: This study reveals the importance of trust in the health sector and the factors that affect it. More detailed studies on practices that will increase confidence in the importance of this issue and measures that will reduce distrust will make a great contribution to this issue.
\end{abstract}

Keywords: Trust, mistrust, physician trust, medical mistrust, self-trust

\section{Introduction}

The demand for and use of health systems show the strength of a health system. In the traditional context, strong health systems are defined by factors such as human resources capacity, financing, information systems, and governance, as well as their ability to provide adequate service coverage and quality of care (1). Equally important, however, in the demand and use of services is the trust in the health system by the population it is intended to serve. Trust is generally understood

\footnotetext{
${ }^{1}$ Asst. Prof. Dr., Sabahattin Zaim University, Faculty of Health Sciences, Health Management Department, halil.sengul@izu.edu.tr (iD) Orcid ID: 0000-0001-5745-0369

${ }^{2}$ Ph.D. Candidate, Uskudar University, Faculty of Health Sciences, Health Management Department, arzublt80@gmail.com (D) Orcid ID: 0000-0001-7362-5667
} 
Sengul, H., \& Bulut, A. (2020). Determination of the relationship between physician trust, medical mistrust, and selfconfidence in the health services provided in Turkey. Journal of Human Sciences, 17(4), 1222-1234. doi:10.14687/ihs.v17i4.6095

as the expectation that one's word, promise, written communication, or someone else's actions can be trusted (2). Because the concept of trust is always vague and fuzzy, it is a difficult concept to define and research. Trust is an important component of social capital. Trust can further use community capabilities to support the collective value and health of the social structures of society (3). Trust plays an important role in the health system, where all stakeholders of the system are highly interrelated. Health services, as a part of the health system; It is a set of services provided by people, in which interactions between people, patients, physicians, nurses, pharmacists, insurers, suppliers, policymakers, and other stakeholders play an important role. As Gilson puts it, "trust is important for health systems because cooperation across the system is a necessary factor for health production" (4). Trust measures can be used by healthcare professionals, health program practitioners, and researchers to monitor and evaluate their trust in building a reliable health system that can lead people to better health outcomes. Trust has been associated with a number of key healthcare goals, ranging from access to care, health-related behavior, continuity and quality of care, to self-reporting health status. The first and foremost relationship between trust and healthcare is the relationship with better access and use of medical care (5). It is also highly correlated with physician satisfaction and loyalty (6). Trust increases the likelihood of patients recommending treatment to others and may affect the effectiveness and compliance of treatment among patients (7). The quality of the interaction, the degree of informing, the level of autonomy in decision making, continuity of care, and the level of participation in behavioral change are affected by the trust in the relationship between the patient and the service provider. Finally, there is some evidence that trust is indeed related to the health reported by patients (8) Trust is also important at the institutional level, as people's trust in hospitals, insurance companies, and health systems can affect service use and hence economic and political viability (5). Trust in medical practices and medical institutions influence attitudes and behaviors at many levels that have consequences for everything from national vaccination campaigns to physicianpatient relationships, care-seeking, information disclosure, treatment adherence, and even the placebo effect. Trust in a health system can also be influenced by professional norms and power dynamics among nurses, physicians, and other healthcare organizations, and can shape attitudes and practices towards patients (9). Trust also plays a critical role in public-private health partnerships (10), as it manages the problem of information asymmetry and reduces the transaction costs of large amounts of external monitoring (11). Having a reliable health system can contribute to the development of broader social value and social order (1). Patients' trust in healthcare professionals is at the center of clinical practice $(12,13)$. The 'Medical Council' in the UK states that patients should be able to trust physicians regarding their lives and health, and maintaining trust is a fundamental obligation for physicians (14). Similar obligations are part of the code of conduct for other health professionals such as nurses (15) or psychotherapists. Trust has long been recognized as an important element of the therapeutic relationship between patients and their physicians $(14,18)$. Trust is particularly important in the context of vulnerability, complex information, and uncertainty $(19,20)$. Security means more than a lack of trust. (20). Trust is a critical determinant of demand for services and plays an important role in user-provider interactions at the center of the healthcare system trust in healthcare providers has been associated with increased access to healthcare services, compliance with treatment, continuity of care, quality of care, and even self-reported health status $(21,22)$. On the other hand, weakened health systems cause mistrust (23). From a system perspective, it is important to gather trust at the community level or the trust of individuals (24). In healthcare, patients naturally rely on professionals for their clinical expertise and emotional support in healthcare decisions. In this context, it has been suggested that trust in healthcare professionals is essential for effective treatments $(25,26)$ and essential for patient-centered care $(27)$. Besides such a deontological obligation of trust, theoretical models describe mechanisms for how a trust can affect health outcomes $(28,30,32)$. Lack of trust in physicians is associated with decreased patient satisfaction and less compliance with treatment and examination recommendations $(33,36)$. In addition, low trust and distrust in the health system is associated with worse health status $(37,38)$. Therefore, maintaining 
Sengul, H., \& Bulut, A. (2020). Determination of the relationship between physician trust, medical mistrust, and selfconfidence in the health services provided in Turkey. Journal of Human Sciences, 17(4), 1222-1234. doi:10.14687/jhs.v17i4.6095

and developing trust is an important goal for the medical profession and health system. Trust has multiple dimensions in which loyalty and the principle of putting patients' interests above others are an important component (33). It has been demonstrated and conceptualized with the results of randomized controlled studies that trust in the healthcare provider with respect to the patientclinician relationship has a significant relationship (39). Therefore, the question is whether trust in the healthcare professional is also related to the health of patients. Empirical evidence for this question comes from a growing number of studies that report correlations between trust measures and patients' health outcomes. In different studies, health outcomes cover different dimensions such as some objectively measured indicators (eg CD4 cell counts) (40), clinical observations (eg clinical diagnoses) (41), and patients' subjective self-ratings (eg patient satisfaction) (42). The relationship between trust and health outcomes was found to be different in individual studies. For example, in a sample of a patient with diabetes, trust in the healthcare professional has been found to be positively associated with objective and subjective health outcomes (glycemic control, health-related quality of life, and patient satisfaction) (32). In another study, on the contrary, a significant relationship was not found between trust in healthcare professionals and subjective outcomes (blood pressure control) in patients with hypertension (43). In the absence of a systematic and comprehensive summary of available evidence, the change in observed health outcomes and disease complications complicates the conclusions on the relationship between trust and health. Empirical verification of the presumed relationship between trust and health outcomes will strengthen the hitherto ethically derived claims for reliable and patient-centered relationships in clinical settings $(13,44,45)$. Only in the last few decades researchers have begun measuring and analyzing trust in the healthcare system. So far, studies examining the credibility of the physician in Turkey, even though confidence in the health service and by analyzing physician confidence in it there is no work. This article attempts to fill this gap by asking the following research questions:

1-At what level is the trust of the society in the health system?

2-At what level is the trust of the society in physicians?

3-What are the hidden variables affecting the trust in the physician?

Finding answers to the above questions will guide us to estimate the overall relationship between trust and health outcomes.

\subsection{Type of the Study}

\section{Material and Method}

This study was carried out in descriptive design.

\subsection{Sample Group}

The sample group of the study consisted of a total of 561 people including 217 male and 344 female, who were aged between 18 and 70 years, who were living in different cities in Turkey, and who agreed to participate in the study.

\subsection{Data Collection Tools}

In the study, "Personal Information Form" and medical mistrust scale (MMS), physician trust scale (PTS) and generalized trust inventory infrastructure scale (GTIS) were used as data collection tools.

\subsubsection{Socio-Demographic Information Form}

In order to collect socio-demographic information about the participants, the variables prepared by the researcher were questioned under 3 different headings. Participants ' gender, marital status, age, occupation, educational status, income status, type of institution referred, type of Social Security, individual health status and history of chronic disease are shown in Table 1. In Table 2, participants ' health services benefit characteristics; whether the situation is regularly navigated the medical staff and the physician, seeing the respect and attention from the physician, the physician 
Sengul, H., \& Bulut, A. (2020). Determination of the relationship between physician trust, medical mistrust, and selfconfidence in the health services provided in Turkey. Journal of Human Sciences, 17(4), 1222-1234. doi:10.14687/ihs.v17i4.6095

enough time to the allocation status of the patient, the physician involving patients in decisions about treatment status, service satisfaction, health status, although in the last 1 years have had health problems, health services deferral status, and the printing condition prescribed in the last 1 year has been questioned whether it is Physician's preference. Physical damage or abuse they are experiencing in delivering health services with the situation they observed any damage of the damage type from physical damage or abuse, which is a professional group of employees who, when exposed to physical damage or abuse, physical damage or abuse, don't disturb the people in the situation and, therefore, their state variables are shown in Table 3 for employees to complain.

\subsubsection{Medical Mistrust Scale (MMS)}

MMS is a 4-point Likert-type scale consisting of 17 items, ranging from "I agree a lot", "I agree", "I disagree" and "I disagree at all", which measures trust in health institutions. MMS was adapted to Turkish by Sengul and Bulut over 263 people, reliability and validity analyses were performed (47). In the studies of Sengul and Bulut, they determined a 2-factor structure consisting of 8 substances in total. The MMS total score was found to be 0.82 of Cronbach's alpha value.

\subsubsection{Physician Trust Scale (PTS)}

The physician trust scale is a Likert-type scale of 5, consisting of 11 items ranging from "I agree very much", "I agree", "I disagree", "I disagree" and "I disagree at all", which measures the physician's interest in the patient's medical needs. Reliability and validity analyses were made by PTS Sengul and Bulut, adapted to Turkish by 263 people (47). In the studies of Sengul and Bulut, they determined a single-factor structure in which all 7 substances are covered. The total score of the PTS Cronbach alpha value was found to be 0.88 .

\subsubsection{Generalized trust inventory infrastructure scale (GTIS)}

GTIS "for me it is very true or very much agree", "agree or right for me", "for me, sometimes true, or I'm indecisive", "disagree or wrong for me" and "very wrong to me, or completely disagree" ranging from consists of 20 items, and the mistrust of the individual measure 5-point Likerttype scale. GTIS was adapted to Turkish by Sengul and Bulut over 263 people and reliability and validity analyses were performed (47). In the studies of Sengul and Bulut, they determined a 3-factor structure consisting of 11 substances in total. The total score of the GTIS was found to be Cronbach alpha value 0.74 .

\subsection{Data Collection Method}

The test method conducted in computer environment applied to 561 participants, who agreed to participate in the research with their own consent, was used as the data collection method in the study. According to the results of a meta-analysis carried out in Turkey, there was no statistically significant difference between the paper and pencil form the student performances shown in the tests applied in a computer environment (48). The form of the scale applied to the participants in the study was sent to the participants in computer environment. After the sufficient sample size was reached in the study, the application was terminated.

\subsection{Ethical Direction of the Research}

In the study, decision of the ethics committee was taken for the non-interventional practices from the ethics committee of Sabahattin Zaim University (Dated 2020 with no. 06).

\subsection{Data Analysis}

Data analysis was performed by using SPSS (Statistical Package for Social Sciences) for Windows 24 program. According to the answers of a total of 561 participants, who accepted to participate in the research and were living at different cities in Turkey, the distribution of the questions in the personal information form was determined by the frequency analysis and descriptive statistics were conducted. 
Sengul, H., \& Bulut, A. (2020). Determination of the relationship between physician trust, medical mistrust, and selfconfidence in the health services provided in Turkey. Journal of Human Sciences, 17(4), 1222-1234. doi:10.14687/ihs.v17i4.6095

In the study, parametric test statistics were used to compare the data. One-way variance analysis and pearson correlation analysis test statistics were used to compare the total score averages obtained from the scale. $\mathrm{P}<0.050$ and $\mathrm{p}<0.001$ were determined for the significance level.

\section{Results}

Table 1 shows socio-demographic characteristics of the participants. The average age was $37.8 \pm 12.1(\min =18 ; \max =70)$ and the genders of the participants were male with $61.3 \%$ female and $38.7 \%$ male.

It was determined that the education level of the participants was undergraduate at $55.4 \%$, their marital status was married at 60.8\%, and the highest rate of income was 2001-4000 TL with $28.5 \% .57 \%$ of the participants prefer the state hospital, their social security is SSI (Social Security Institution) with $86.6 \%$, they are civil servants with $24.4 \%$, they are in good health with $74 \%$, they have a history of chronic disease with $25.7 \%$.

Table 1. Socio-demographic characteristics of the participants $(n=561)$

\begin{tabular}{|c|c|c|c|}
\hline \multicolumn{4}{|l|}{ Age: Mean $=37.8 \pm 12.1$} \\
\hline Variables & Groups & $\mathbf{n}$ & $\%$ \\
\hline \multirow{2}{*}{ Gender } & Female & 344 & 61.3 \\
\hline & Male & 217 & 38.7 \\
\hline \multirow{2}{*}{ Marital status } & The married & 341 & 60.8 \\
\hline & Single & 220 & 39.2 \\
\hline \multirow{4}{*}{ Education status } & Primary education & 38 & 6.8 \\
\hline & High school & 82 & 14.6 \\
\hline & License & 311 & 55.4 \\
\hline & Graduate & 130 & 23.2 \\
\hline \multirow{6}{*}{ Income status } & 1000 TRY and below & 47 & 8.4 \\
\hline & 1001-2000 TRY & 123 & 21.9 \\
\hline & 2001-4000 TRY & 160 & 28.5 \\
\hline & 4001-6000 TRY & 148 & 26.4 \\
\hline & 6001-8000 TRY & 59 & 10.5 \\
\hline & 8001-10000 TRY & 24 & 4.3 \\
\hline \multirow{4}{*}{$\begin{array}{l}\text { Referenced types of } \\
\text { institutions }\end{array}$} & State hospital (1) & 320 & 57.0 \\
\hline & Private hospital (2) & 173 & 30.8 \\
\hline & University hospital (3) & 54 & 9.6 \\
\hline & I don't want to say (4) & 14 & 2.5 \\
\hline \multirow{4}{*}{ Social security type } & General health insurance & 16 & 2.9 \\
\hline & Private insurance & 22 & 3.9 \\
\hline & Social security institution & 486 & 86.6 \\
\hline & I Have No Social Security & 37 & 6.6 \\
\hline \multirow{4}{*}{ Health status } & Bad & 13 & 2.3 \\
\hline & Good & 415 & 74.0 \\
\hline & I do not know & 120 & 21.4 \\
\hline & I do not want to say & 13 & 2.3 \\
\hline \multirow{2}{*}{ Presence of chronic disease } & Yes & 144 & 25.7 \\
\hline & No & 417 & 74.3 \\
\hline \multirow{7}{*}{ Profession } & Civil servant & 137 & 24.4 \\
\hline & Housewife & 76 & 13.5 \\
\hline & Retired & 41 & 7.3 \\
\hline & Student & 101 & 18.0 \\
\hline & Your own business & 28 & 5.0 \\
\hline & Public worker & 50 & 8.9 \\
\hline & Paid employee & 128 & 22.8 \\
\hline
\end{tabular}


Sengul, H., \& Bulut, A. (2020). Determination of the relationship between physician trust, medical mistrust, and selfconfidence in the health services provided in Turkey. Journal of Human Sciences, 17(4), 1222-1234. doi:10.14687/jhs.v17i4.6095

Table 2 shows, It was determined that $55.8 \%$ of participants had medical personnel with whom they went regularly, $34.9 \%$ had a physician with whom they went regularly, $65.8 \%$ received respect and attention from their physician, $65.4 \%$ devoted enough time to themselves, and $64.3 \%$ included themselves in the decisions about treatment of the physician. $77.7 \%$ of the participants were satisfied with the health service, $36.4 \%$ had health problems in the last 1 year, $66.7 \%$ had been prescribed to them in the last 1 year and $70.4 \%$ had no physician preferences.

Table 2. Characteristics of participants ' use of health services $(n=561)$

\begin{tabular}{|c|c|c|c|}
\hline Variables & Group & $\mathbf{n}$ & $\%$ \\
\hline \multirow{3}{*}{$\begin{array}{l}\text { Are there any health personnel } \\
\text { that go regularly? }\end{array}$} & Yes & 313 & 55.8 \\
\hline & No & 243 & 43.3 \\
\hline & I do not want to say & 5 & 0.9 \\
\hline \multirow{3}{*}{$\begin{array}{l}\text { Is there a physician you go to } \\
\text { regularly? }\end{array}$} & Yes & 196 & 34.9 \\
\hline & No & 352 & 62.7 \\
\hline & I do not want to say & 13 & 2.3 \\
\hline \multirow{4}{*}{$\begin{array}{l}\text { Does the physician show } \\
\text { sufficient respect and } \\
\text { attention? }\end{array}$} & He showed respect and attention & 369 & 65.8 \\
\hline & Did not show respect and attention & 21 & 3.7 \\
\hline & I don't have a physician regularly & 165 & 29.4 \\
\hline & I do not want to say & 6 & 1.1 \\
\hline \multirow{4}{*}{$\begin{array}{l}\text { Does the physician spare } \\
\text { enough time? }\end{array}$} & Took enough time & 367 & 65.4 \\
\hline & Didn't take enough time & 128 & 22.8 \\
\hline & I do not want to say & 44 & 7.8 \\
\hline & Ambivalent & 22 & 3.9 \\
\hline \multirow{4}{*}{$\begin{array}{l}\text { Does the physician include } \\
\text { you in decisions about } \\
\text { treatment? }\end{array}$} & İnclude & 361 & 64.3 \\
\hline & Don't include & 113 & 20.1 \\
\hline & I do not want to say & 19 & 3.4 \\
\hline & Ambivalent & 68 & 12.1 \\
\hline \multirow{4}{*}{$\begin{array}{l}\text { Are you satisfied with the } \\
\text { health service you received? }\end{array}$} & Satisfied (1) & 436 & 77.7 \\
\hline & Don't satisfied (2) & 90 & 16.0 \\
\hline & Ambivalent (3) & 14 & 2.5 \\
\hline & I do not want to say (4) & 21 & 3.7 \\
\hline \multirow{4}{*}{$\begin{array}{l}\text { Have you been postponed in } \\
\text { the last one year despite } \\
\text { having a health problem? }\end{array}$} & Postponed & 319 & 56.9 \\
\hline & Don't postponed & 204 & 36.4 \\
\hline & I do not know & 32 & 5.7 \\
\hline & I do not want to say & 6 & 1.1 \\
\hline \multirow{4}{*}{$\begin{array}{l}\text { Have you had a prescription in } \\
\text { the last one year? }\end{array}$} & I did not have a prescription & 153 & 27.3 \\
\hline & I got a prescription & 374 & 66.7 \\
\hline & I do not know & 31 & 5.5 \\
\hline & I do not want to say & 3 & 0.5 \\
\hline \multirow{4}{*}{ Physician preferences } & No preference & 395 & 70.4 \\
\hline & Female & 10 & 1.8 \\
\hline & Male & 30 & 5.3 \\
\hline & Prefer expertise & 126 & 22.5 \\
\hline
\end{tabular}

Table 3 shows it is determined that $77.7 \%$ of the participants were subjected to ill-treatment when physical harm or maltreatment while receiving healthcare services is examined. $45.5 \%$ of those who were maltreated or physically harmed stated that physicians were among the occupational group maltreated. $15 \%$ of the time the maltreatment occurred was within the last 1-3 years, and $75.5 \%$ stated that this situation disturbed them very much and $35.9 \%$ complained about this situation. 
Sengul, H., \& Bulut, A. (2020). Determination of the relationship between physician trust, medical mistrust, and selfconfidence in the health services provided in Turkey. Journal of Human Sciences, 17(4), 1222-1234. doi:10.14687/jhs.v17i4.6095

Table 3. Physical harm or maltreatment in healthcare $(n=179)$

\begin{tabular}{|c|c|c|c|}
\hline Variables & Group & $\mathbf{n}$ & $\%$ \\
\hline \multirow{3}{*}{ Damage type $*$} & Physical harm & 29 & 13.2 \\
\hline & Abuse & 171 & 77.7 \\
\hline & Other & 20 & 9.1 \\
\hline \multirow{5}{*}{$\begin{array}{l}\text { Physical harm or abuse } \\
\text { employee } *\end{array}$} & Physician & 148 & 45.5 \\
\hline & Nurse & 63 & 19.4 \\
\hline & Consultation steering staff & 53 & 16.3 \\
\hline & Security & 8 & 2.5 \\
\hline & Other Staff & 53 & 16.3 \\
\hline \multirow{5}{*}{ Time of physical harm or abuse } & Less than 1 year & 66 & 11.8 \\
\hline & $1-3$ years & 84 & 15.0 \\
\hline & $4-7$ years & 33 & 5.9 \\
\hline & Between $8-10$ years & 16 & 2.9 \\
\hline & 11 years and above & 21 & 3.7 \\
\hline \multirow{3}{*}{$\begin{array}{l}\text { Physical harm or abuse making } \\
\text { the person uncomfortable }\end{array}$} & Never bothered & 7 & 3.2 \\
\hline & A little bothered & 47 & 21.4 \\
\hline & Bothered too much & 166 & 75.5 \\
\hline \multirow{2}{*}{ Status of making a complaint } & I complained & 79 & 35.9 \\
\hline & I did not complain & 141 & 64.1 \\
\hline
\end{tabular}

* More than one option has been used.

In our study, the mean, standard deviation and Cronbach alpha value of the participants' overall score and sub-dimensions of the Medical Mistrust Scale (MMS), Physician Trust Scale (PTS), and Generalized Trust Inventory Infrastructure Scale (GTIS) are shown in Table 4.

Table 4. Mean and standard deviation values of variables

\begin{tabular}{lccc}
\hline Dimensions & Mean & Std. Deviation & $\begin{array}{c}\text { Cr.'s } \\
\text { Alpha }\end{array}$ \\
\hline Distrust in the health institution & 9.84 & 2.12 & 0.73 \\
Distrust in healthcare professionals & 9.23 & 1.94 & 0.73 \\
MMS Total & 19.07 & 3.66 & 0.82 \\
Mistrustfulness & 15.30 & 3.94 & 0.77 \\
İntolerance & 4.43 & 1.42 & 0.63 \\
Submissive & 8.76 & 2.16 & 0.66 \\
GTIS Total & 28.49 & 5.45 & 0.74 \\
PTS Total & 24.73 & 4.39 & 0.88 \\
\hline
\end{tabular}

\section{Normal Distribution Test}

According to George, D. \& Mallery, M. (2010), if the Skewness and Kurtosis values are between $+2.0-2.0$, the data is normally distributed (47). It was determined that MMS, PTS, GTIS and its factors were normally distributed as seen in Table 5. Accordingly, one-way analysis of variance and Pearson correlation analysis test statistics, which are among the parametric test methods, were used to determine whether the participants differ according to their demographic characteristics. 
Sengul, H., \& Bulut, A. (2020). Determination of the relationship between physician trust, medical mistrust, and selfconfidence in the health services provided in Turkey. Journal of Human Sciences, 17(4), 1222-1234. doi:10.14687/jhs.v17i4.6095

Table 5. Normal Distribution

\begin{tabular}{lcc}
\hline \multirow{2}{*}{ MMS Total } & Skewness & 0.29 \\
\cline { 2 - 3 } Distrust in the health institution & Kurtosis & 1.38 \\
\hline \multirow{2}{*}{ Distrust in healthcare professionals } & Skewness & 0.16 \\
\cline { 2 - 3 } & Kurtosis & 0.45 \\
\hline \multirow{2}{*}{ PTS Total } & Skewness & 0.38 \\
\cline { 2 - 3 } & Kurtosis & 1.30 \\
\hline \multirow{2}{*}{ GTIS Total } & Skewness & -0.63 \\
\cline { 2 - 3 } & Kurtosis & 1.50 \\
\hline \multirow{2}{*}{ Mistrustfulness } & Skewness & 0.02 \\
\cline { 2 - 3 } & Kurtosis & 0.19 \\
\hline \multirow{2}{*}{ Intolerance } & Skewness & 0.23 \\
\hline \multirow{2}{*}{ Submissive } & Kurtosis & -0.12 \\
\hline
\end{tabular}

In our study, Pearson's correlation coefficients were calculated to examine the relationship between the participants' MMS, PTS and GTIS and their sub-factor scores. As a result of the Pearson correlation analysis, a statistically significant positive and negative relationship was found between the scores at the level of $\mathrm{p}<0.05$ and $\mathrm{p}<0.001$ (Table 6 ).

According to these results, there is a moderately negative correlation between physician trust and medical distrust $(\mathrm{r}=-0.64$; and $\mathrm{p}<0.001)$. There is a low-level negative correlation between self-confidence and physician trust $(r=-0.13$; and $\mathrm{p}<0.05)$.

Table 6. Correlation analysis

\begin{tabular}{|c|c|c|c|c|c|c|c|}
\hline & MMS & PTS & GTIS & $\begin{array}{l}\text { Distrust in } \\
\text { the health } \\
\text { institution }\end{array}$ & $\begin{array}{c}\text { Distrust in } \\
\text { healthcare } \\
\text { professionals }\end{array}$ & $\begin{array}{c}\text { Mistr } \\
\text { ustful } \\
\text { ness }\end{array}$ & İntolerance \\
\hline PTS Total & $-0.64 * *$ & & & & & & \\
\hline GTIS Total & $0.10^{*}$ & $-0.13^{*}$ & & & & & \\
\hline $\begin{array}{l}\text { Distrust in the health } \\
\text { institution }\end{array}$ & $0.91 * *$ & $-0.56 * *$ & $0.13^{*}$ & & & & \\
\hline $\begin{array}{l}\text { Distrust in healthcare } \\
\text { professionals }\end{array}$ & $0.89 * *$ & $-0.60 * *$ & 0.05 & $0.62^{* *}$ & & & \\
\hline Mistrustfulness & 0.08 & -0.06 & $0.87^{* *}$ & $0.15^{* *}$ & -0.02 & & \\
\hline İntolerance & $0.09 *$ & $-0.18^{* *}$ & $0.34^{* *}$ & 0.02 & $0.14^{* *}$ & 0.02 & \\
\hline Submissive & 0.06 & $-0.10^{*}$ & $0.71 * *$ & $0.040^{*}$ & 0.08 & $0.37 * *$ & $0.17^{* *}$ \\
\hline
\end{tabular}

$* p<0.05, * * p<0.001$

In our study, the comparison of the participants, MMS, PTS, and GTIS levels according to the health service satisfaction groups was analyzed with one-way variance test statistics and the results are shown in Table 7. In our study, the difference between the groups and within the groups was found to be statistically significant according to the variable of satisfaction with health service in the total scores of MMS, PTS, and GTIS ( $p<0.05$; $p<0.001$ ). When the group in which the difference originated from MMS, the total scores of those who were not satisfied with the health service were found to be higher than the total scores of satisfied and undecided. It is seen that the eta squared $(\eta 2)$ value calculated for the MMS total score according to the satisfaction of the participants with the health service is medium $(\eta 2: 0.101)$. When the group originated from the difference for the PTS, the total scores of those who were satisfied with the health service were higher than the total scores of those who did not want to tell, the total scores of the undecided, the total scores of the dissatisfied, and the total scores of those who did not want to say, than the total scores of the dissatisfied. It is seen that the eta squared $(\eta 2)$ value calculated for the total PTS score 
Sengul, H., \& Bulut, A. (2020). Determination of the relationship between physician trust, medical mistrust, and selfconfidence in the health services provided in Turkey. Journal of Human Sciences, 17(4), 1222-1234. doi:10.14687/ihs.v17i4.6095

according to the satisfaction of the participants with the health service is high ( $\eta 2: 0.222)$. For GTIS, when the group originating from the difference was analyzed, the total scores of those who were satisfied with the health service were higher than the total scores of those who were not satisfied. It is seen that the eta squared $(\eta 2)$ value calculated for the GTIS total score according to the satisfaction of the participants with the health service is low $(\eta 2: 0.101)$.

Table 7. ANOVA table according to the groups of participants' satisfaction levels from health services $(n=561)$

\begin{tabular}{|c|c|c|c|c|c|c|c|c|}
\hline & & Sum of squares & df & Mean Square & $\mathbf{F}$ & $\mathrm{p}$ & $\eta^{2}$ & Difference \\
\hline \multirow{3}{*}{ MMS Total } & Between groups & 757.270 & 3 & 252.423 & \multirow{3}{*}{20.849} & \multirow{3}{*}{$<0.001$} & \multirow{3}{*}{0.101} & \multirow{3}{*}{$\begin{array}{l}2>1 \\
2>3\end{array}$} \\
\hline & In-group & 6743.878 & 557 & 12.108 & & & & \\
\hline & Total & 7501.148 & 560 & & & & & \\
\hline \multirow{3}{*}{ PTS Total } & Between groups & 2400.301 & 3 & 800.100 & \multirow{3}{*}{53.086} & \multirow{3}{*}{$<0.001$} & \multirow{3}{*}{0.222} & $1>2$ \\
\hline & In-group & 8394.972 & 557 & 15.072 & & & & $1>4$ \\
\hline & Total & 10795.273 & 560 & & & & & $\begin{array}{l}3>2 \\
4>2\end{array}$ \\
\hline \multirow{3}{*}{ GTIS Total } & Between groups & 235.708 & 3 & 78.569 & \multirow{3}{*}{2.670} & \multirow{3}{*}{$0.047^{*}$} & \multirow{3}{*}{0.014} & \multirow{3}{*}{$2>1$} \\
\hline & In-group & 16392.520 & 557 & 29.430 & & & & \\
\hline & Total & 16628.228 & 560 & & & & & \\
\hline
\end{tabular}

${ }^{*} p<0.05$ Difference $=$ Satisfied (1), Don't satisfied (2), Ambivalent (3), I do not want to say (4)

In our study, the comparison of the participants' TDS, DAS and VAS levels according to the health institution groups applied was analyzed with one-way variance test statistics and the results are shown in Table 8 . In our study, the difference between the groups and within the groups was not found to be statistically significant according to the health institution variable of the participants' total scores of DAS and VAS ( $\mathrm{p}>0.05$ ). In our study, the difference between the groups and within the groups was found to be statistically significant in terms of the total scores of TGÖ, according to the health institution variable applied ( $p=0.033 ; \mathrm{p}<0.05)$. When the group originated from the TDS, the difference between the groups was found to be higher than the total scores of those who applied to private hospitals. It is seen that the eta squared $(\eta 2)$ value calculated for the total score of TGÖ is small ( $\eta 2: 0.016)$ according to the health institution applied.

Table 8. ANOVA table of the participant groups according to the type of health institution applied $(n=561)$

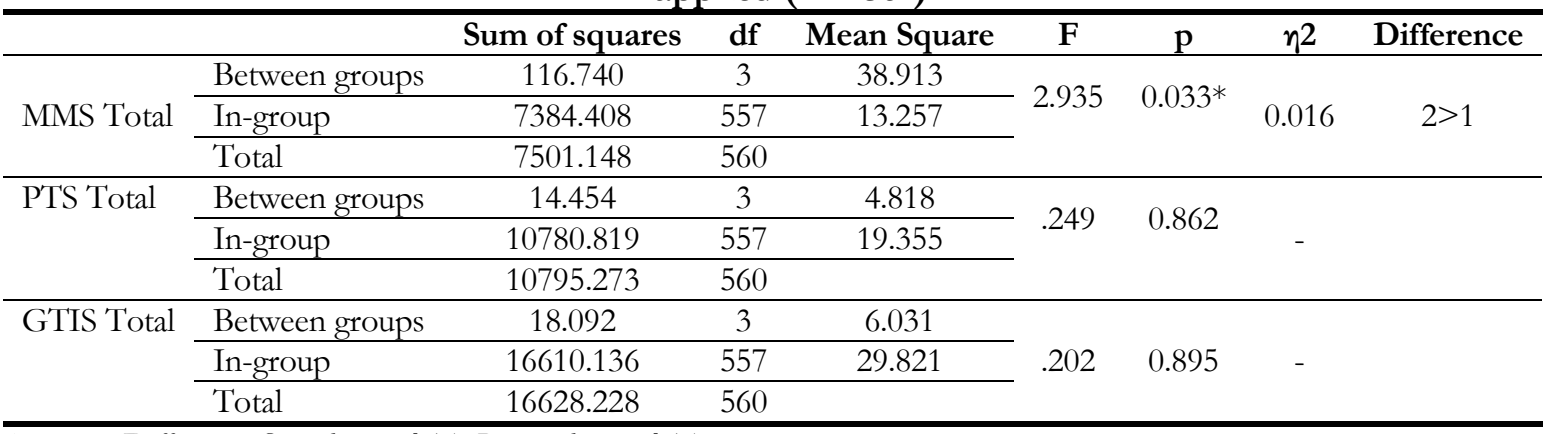

${ }^{*} p<0,05$ Difference=State hospital (1), Private hospital (2)

\section{Discussion and Conclusion}

The concept of trust has multiple dimensions and is situationally variable. Therefore, despite the conceptualization of the patient's trust in the system and the physician, empirical observations have rarely offered confirmation on this issue.

In this research, situational factors; patient characteristics(characteristics of health services utilization, regularly navigated the medical staff and the physician status, presence of chronic disease), the characteristics of the health system( health condition, satisfaction from the service), physicians 
Sengul, H., \& Bulut, A. (2020). Determination of the relationship between physician trust, medical mistrust, and selfconfidence in the health services provided in Turkey. Journal of Human Sciences, 17(4), 1222-1234. doi:10.14687/jhs.v17i4.6095

and other healthcare professionals to bound states (the respect and attention from the physician, seeing the physician enough time to the allocation status of the patient, the physician involving patients in decisions about the treatment status and the situation of physical harm or abuse in health services), we saw it as an opportunity to develop inadequate theorizing and assertions by generalizing previous empirical findings on how patients shaped their trust in a physician or distrust of the system. In doing this study, we also focused on previous recommendations $(7,19)$.

In our study, it was determined that the average number of applications to a health institution in the last year of participants was 5.07, and the average number of days of hospitalization in hospitalists was 3.52 days. In the yearbook of Health Statistics of the Ministry of Health, in 2018, hospitals published the number of applications as 6.1 and the average day of stay of inpatient patients as 4.1 (49).

It was determined that $55.8 \%$ of participants had medical personnel with whom they went regularly, 34.9\% had a physician with whom they went regularly, $65.8 \%$ received respect and attention from their physician, $65.4 \%$ devoted enough time to themselves, and $64.3 \%$ included themselves in the decisions about treatment of the physician. $77.7 \%$ of respondents were satisfied with health care. Ugur and Tirmik examined the statistics made by the Turkish Statistical Institute between 2003 and 2016 and found that the overall level of satisfaction with health services was 3.59 out of 5 points in their study, which had a sample number of 205.060 people. This rate shows that most people's satisfaction with health care is slightly above the average (50). This rate is close to the rate we found in our study, but it can be said that satisfaction is slightly increased.

The Health Transformation Program implemented in Turkey also affected the relations between the physician and the patient and changed the patient profile. Both quick and easy access to information and the impact of practices such as Patient Rights, patients want accurate, understandable, comprehensive and reliable information to be given to them. Anxiety, fear and uncertainty caused by the disease can only be eliminated by the patient's unconditional trust in the physician. The formation of trust in the physician will minimize the stress and negative attitudes that occur due to the stress experienced by the patient. The resulting confidence will also affect the patient's adaptation process to treatment, and the patient will not experience tides between options such as treatment options, alternative medicine practices (51). This, in turn, will lead to increased confidence in the health system in general. As a matter of fact, in our study, there was a moderate negative relationship between physician trust and medical distrust.

There are many disciplines that work on the concept of trust. Trust is the foundation of social order in a society. In order to understand what, how, and why people trust, and how this trust affects social relationships, psychologists, sociologists, anthropologists, and academics working in organizational behavior have conducted many studies. Research has shown that trust is an important part of a healthy personality, as well as an important component in relationships with social institutions (52). In parallel, our study also showed that there is a low-level positive relationship between individual self-confidence and medical mistrust. In other words, medical mistrust increases as an individual's level of mistrust increases. In addition, there is a low-level negative relationship between an individual's self-confidence and trust in the physician. In other words, as self-confidence increases, confidence in the physician also decreases. Causes of medical mistrust include dissatisfaction with the health service. According to the results of our study, the total scores of those who were dissatisfied with health care were higher than the total scores of those who were satisfied and unstable. The same applies to trust in the physician.

Private hospitals, University Hospitals and public hospitals have entered a race in the provision of health services with the Health Transformation Program. This race continues to ensure patient loyalty as well as providing better quality health care (53). Thus, patients ' options have increased while receiving health care. In the results of our study, it is seen that a third of the participants prefer private hospitals. When we looked at the levels of medical mistrust relative to the preferred hospital, it was found that the levels of medical mistrust of patients going to private 
Sengul, H., \& Bulut, A. (2020). Determination of the relationship between physician trust, medical mistrust, and selfconfidence in the health services provided in Turkey. Journal of Human Sciences, 17(4), 1222-1234. doi:10.14687/jhs.v17i4.6095

hospitals exceeded the levels of medical mistrust of patients going to public hospitals. This condition is commonly associated with distrust of private health institutions in society. Social media and the press have a large share of negative news in the emergence of this distrust in society (53).

A sense of trust is of great importance to professional professions. Failure to establish trust, especially in an industry where information asymmetry is too high, such as the health sector, also poses important problems for both employees and society. In a health system that you do not trust, many situations, such as applying for health care, adapting to the given or recommended treatmentsaccepting, respecting the health worker, will also not work as they should. Because this condition will also disrupt treatment processes, it actually creates a dangerous situation from the point of view of Public Health. Patients will not ask for medical care and treatment until they reach an institution they trust or a physician they can trust, they will face conditions such as chronic disease or increased severity. Indeed, it is not possible to establish and maintain a patient-physician, patient - health institution relationship without trust. Ensuring or establishing this is also among the requirements of medical ethics. In our study, confidence/distrust of society in the system and physician in general was analyzed. More detailed studies on practices to increase this confidence and measures to reduce distrust will contribute greatly to this issue.

\section{References}

1. World Health Organization. Everybody's business: strengthening health systems to improve health outcomes-WHO’s framework for action. Geneva: World Health Organization; 2007.

2. Ozawa, S., \& Sripad, P. (2013). How do you measure trust in the health system? A systematic review of the literature. Social science \&o medicine, 91, 10-14.

3. Carpiano, R. M., \& Fitterer, L. M. (2014). Questions of trust in health research on social capital: what aspects of personal network social capital do they measure?. Social science \& medicine, 116, 225-234.

4. Gilson, L. (2003). Trust and the development of health care as a social institution. Social science \& medicine, 56(7), 1453-1468.

5. Russell, S. (2005). Treatment-seeking behaviour in urban Sri Lanka: trusting the state, trusting private providers. Social science \& medicine, 61(7), 1396-1407.

6. Safran, D. G., Kosinski, M., Tarlov, A. R., Rogers, W. H., Taira, D. A., Lieberman, N., \& Ware, J. E. (1998). The Primary Care Assessment Survey: tests of data quality and measurement performance. Medical care, 728-739.

7. Hall, M. A., Zheng, B., Dugan, E., Camacho, F., Kidd, K. E., Mishra, A., \& Balkrishnan, R. (2002). Measuring patients' trust in their primary care providers. Medical care research and review, 59(3), 293-318.

8. Wang, H., Schlesinger, M., Wang, H., \& Hsiao, W. C. (2009). The flip-side of social capital: the distinctive influences of trust and mistrust on health in rural China. Social Science \& Medicine, 68(1), 133-142.

9. Birungi, H. (1998). Injections and self-help: risk and trust in Ugandan health care. Social science \& medicine, 47(10), 1455-1462.

10. Zarychta, A. (2015). Community trust and household health: a spatially-based approach with evidence from rural Honduras. Social Science \& Medicine, 146, 85-94.

11. Ozawa, S., \& Stack, M. L. (2013). Public trust and vaccine acceptance-international perspectives. Human vaccines \& immunotherapeutics, 9(8), 1774-1778.

12. Coulter A. Patients' views of the good physician. Bmj. 2002; 325(7366):668-9. PubMed Central PMCID: PMC1124204. PMID: 12351342

13. Mechanic, D., \& Schlesinger, M. (1996). The impact of managed care on patients' trust in medical care and their physicians. Jama, 275(21), 1693-1697.

14. General Medical Council. Duties of a physician: The duties of a physician registered with the General Medical Council [cited 201627 Jan]. 
Sengul, H., \& Bulut, A. (2020). Determination of the relationship between physician trust, medical mistrust, and selfconfidence in the health services provided in Turkey. Journal of Human Sciences, 17(4), 1222-1234. doi:10.14687/jhs.v17i4.6095

Available from: $\quad$ https://www.gmc-uk.org/ethical-guidance/ethical-guidance-forphysicians/good-medical-practice/duties-of-a-physician

15. Nursing \& Midwifery Council (NMC). The Code for nurses and midwives: Read The Code online 2015 [cited 201627 Jan]. Available from: http://www.nmc.org.uk/standards/code/read-the-codeonline/

16. The British Psychological Society. Code of Ethics and Conduct: Guidance published by the Ethics Commitee of the Bristish Psychology Society 2009 [cited 201627 Jan]. Available from: https://www.bps.org.uk/sites/www.bps.org.uk/files/Policy/Policy\%20$\%$ 20Files $/$ Code $\% 20$ of $\% 20$ Ethics $\% 20$ and $\% 20$ Conduct $\% 20 \% 282009 \% 29$.pdf

17. Pearson, S. D., \& Raeke, L. H. (2000). Patients' trust in physicians: many theories, few measures, and little data. Journal of general internal medicine, 15(7), 509-513.

18. Mechanic, D. (1998). The functions and limitations of trust in the provision of medical care. Journal of Health politics, policy and Law, 23(4), 661-686.

19. Mechanic, D., \& Meyer, S. (2000). Concepts of trust among patients with serious illness. Social science \& medicine, 51(5), 657-668.

20. Hall, M. A., Dugan, E., Zheng, B., \& Mishra, A. K. (2001). Trust in physicians and medical institutions: what is it, can it be measured, and does it matter?. The milbank quarterly, 79(4), 613-639.

21. Rowe, R., \& Calnan, M. (2006). Trust relations in health care-the new agenda. The European Journal of Public Health, 16(1), 4-6.

22. Gilbert, T. P. (2005). Impersonal trust and professional authority: exploring the dynamics. Journal of Advanced Nursing, 49(6), 568-577.

23. Jones, J. A., \& Barry, M. M. (2011). Developing a scale to measure trust in health promotion partnerships. Health promotion international, 26(4), 484-491.

24. Bloom, G., Standing, H., \& Lloyd, R. (2008). Markets, information asymmetry and health care: towards new social contracts. Social science \& medicine, 66(10), 2076-2087.

25. Mechanic, D. (1996). Changing medical organization and the erosion of trust. The Milbank Quarterly, 171-189.

26. Goold, S. D. (1998). Money and trust: relationships between patients, physicians, and health plans. Journal of Health Politics, Policy and Law, 23(4), 687-695.

27. Hall, M. A. (2001). Arrow on trust. Journal of Health Politics, Policy and Law, 26(5), 1131-1144.

28. Calnan, M., \& Rowe, R. (2006). Researching trust relations in health care. Journal of health organization and management.

29. Croker, J. E., Swancutt, D. R., Roberts, M. J., Abel, G. A., Roland, M., \& Campbell, J. L. (2013). Factors affecting patients' trust and confidence in GPs: evidence from the English national GP patient survey. BMJ open, 3(5).

30. Benedetti, F. (2013). Placebo and the new physiology of the physician-patient relationship. Physiological reviens, 93(3), 1207-1246.

31. Wampold, B. E., \& Imel, Z. E. (2015). The great psychotherapy debate: The evidence for what makes psychotherapy work. Routledge.

32. Lee, Y. Y., \& Lin, J. L. (2011). How much does trust really matter? A study of the longitudinal effects of trust and decision-making preferences on diabetic patient outcomes. Patient education and counseling, 85(3), 406-412.

33. Safran, D. G., Taira, D. A., Rogers, W. H., Kosinski, M., Ware, J. E., \& Tarlov, A. R. (1998). Linking primary care performance to outcomes of care. Journal of family practice, 47, 213-220.

34. Carpenter, W. R., Godley, P. A., Clark, J. A., Talcott, J. A., Finnegan, T., Mishel, M., ... \& Mohler, J. L. (2009). Racial differences in trust and regular source of patient care and the implications for prostate cancer screening use. Cancer: Interdisciplinary International Journal of the American Cancer Society, 115(21), 5048-5059.

35. Anderson, L. A., \& Dedrick, R. F. (1990). Development of the Trust in Physician scale: a measure to assess interpersonal trust in patient-physician relationships. Psychological reports, 67(3_suppl), 10911100. 
Sengul, H., \& Bulut, A. (2020). Determination of the relationship between physician trust, medical mistrust, and selfconfidence in the health services provided in Turkey. Journal of Human Sciences, 17(4), 1222-1234. doi:10.14687/jhs.v17i4.6095

36. Bickell, N. A., Weidmann, J., Fei, K., Lin, J. J., \& Leventhal, H. (2009). Underuse of breast cancer adjuvant treatment: patient knowledge, beliefs, and medical mistrust. Journal of Clinical Oncology, 27(31), 5160 .

37. Nummela, O., Sulander, T., Rahkonen, O., \& Uutela, A. (2009). The effect of trust and change in trust on self-rated health: A longitudinal study among aging people. Archives of Gerontology and Geriatrics, 49(3), 339-342.

38. Armstrong, K., Rose, A., Peters, N., Long, J. A., McMurphy, S., \& Shea, J. A. (2006). Distrust of the health care system and self-reported health in the United States. Journal of general internal medicine, 21(4), 292.

39. Kelley, J. M., Kraft-Todd, G., Schapira, L., Kossowsky, J., \& Riess, H. (2014). The influence of the patient-clinician relationship on healthcare outcomes: a systematic review and meta-analysis of randomized controlled trials. PloS one, 9(4), e94207.

40. Graham, J. L., Grimes, R. M., Slomka, J., Ross, M., Hwang, L. Y., \& Giordano, T. P. (2013). The role of trust in delayed HIV diagnosis in a diverse, urban population. AIDS and Behavior, 17(1), 266-273.

41. Freburger, J. K., Callahan, L. F., Currey, S. S., \& Anderson, L. A. (2003). Use of the Trust in Physician Scale in patients with rheumatic disease: psychometric properties and correlates of trust in the rheumatologist. Arthritis Care \& Research: Official Journal of the American College of Rheumatology, 49(1), 51 58.

42. Boothroyd, R. A., Rocca, T. D., \& Chen, H. J. (2008). Predictors of enrollees' satisfaction with a county-sponsored indigent health care plan. Evaluation \& the health professions, 31(1), 81-103.

43. Durant, R. W., McClure, L. A., Halanych, J. H., Lewis, C. E., Prineas, R. J., Glasser, S. P., \& Safford, M. M. (2010). Trust in physicians and blood pressure control in blacks and whites being treated for hypertension in the REGARDS study. Ethnicity \& disease, 20(3), 282.

44. Pearson, S. D., \& Raeke, L. H. (2000). Patients' trust in physicians: many theories, few measures, and little data. Journal of general internal medicine, 15(7), 509-513.

45. Wright, E. B., Holcombe, C., \& Salmon, P. (2004). Physicians' communication of trust, care, and respect in breast cancer: qualitative study. Bmj, 328(7444), 864.

46. George, D. (2011). SPSS for windows step by step: A simple study guide and reference, 17.0 update, 10/e. Pearson Education India.

47. Sengul, H. \& Bulut, A. (2020). “T1bbi Güvensizlik Ölçeği ve Doktora Güven Ölçeğinin Türkçe Geçerlik Güvenirlik Çalışması" International Social Sciences Studies Journal, (6);62:1956-1964.

48. Aybek, E. C., Şahin, D. B., Eriş, H. M., Şimşek, A. S., \& Köse, M. (2014). Kağit-kalem ve bilgisayar formunda uygulanan testlerde öğrenci başarisinin karşilaştirildiği çalişmalarin meta-analizi. Asian Joumal of Instruction, 2(2), 18.

49. https://dosyamerkez.saglik.gov.tr/Eklenti/36134,siy2018trpdf.pdf?0

Erişim Tarihi; 23/09/2020

50. Uğur Z \& Tirgil, A. (2018). Sağlıkta Dönüşüm Programı Ve Kamunun Sağlık Hizmetlerinden Memnuniyeti. Ombudsman Akademik, (1), 295-327.

51. Gülcemal, E., \& Keklik, B. (2016). Hastaların Hekimlere Duydukları Güveni Etkileyen Faktörlerin İncelenmesine Yönelik Bir Araştırma: Isparta İli Örneği. Mebmet Akif Ersoy Üniversitesi Sosyal Bilimler Enstitüsü Dergisi, 8(14), 64-87.

52. Seçer, H. Ş. (2009). Profesyonel Mesleklere Ve Profesyonel Bireylere Güven. Kamu-Isş; C:10, $\mathrm{S}: 4 / 2009$

53. Sengul H, Katırc1 Fener S, Kahraman B, Değırmenci S(2016), Hastalarda Kurumsal Ün- İmaj Algıları Ve Etkileri, VI. Uluslararası Sağlıkta Performans ve Kalite Kongresi 2016/Antalya

54. Söylet, Y., \& Mengü, S. C.. (2011). Doktorlara Yönelik İzlenim Ve Tutum Oluşumunun; Yazilı Basında Doktorlara Yönelik Olușturulan Söylem Bağlamında İrdelenmesi. İstanbul Üniversitesi İletișim Fakültesi Dergisi, (40), 101-122. 